\title{
PEMBANGUNAN GAMPONG DENGAN SEMANGAT GOTONG ROYONG MELALUI MUSYAWARAH DAN KETERBUKAAN DI KABUPATEN ACEH BARAT
}

\author{
Teuku Ahmad Yani \\ Fakultas Hukum Universitas Syiah Kuala \\ email: teuku_yani@unsyiah.ac.id
}

\begin{abstract}
Development activities independently by society Gampong is not a new thing in the country of Indonesia, it's just that more development activities based on the limitations of the use of the resources of the gampong both in terms of both financial resources his human. Therefore, mutual is the main way for people to development Gampong. In tune with the enacted law on Gampong, then mutual culture be reduced, where as the presence of State money in Gampong development in to additional energy from the spirit of Indonesia. The results showed that implementing the construction of Gampong, there are still many obstacles, but the existence of the deliberations conducted by Lord Peuet has been able to solve the problem, because the deliberations deliberations remained the leading solutions in gampong daam resolves the problem. In order for the deliberation can be meaningful so any executing development must be open to problems occurred, likewise should willingly and respect any result of deliberation a mutually agreed.
\end{abstract}

Keywords: Gampong, Keuchik, Finance 


\section{PENDAHULUAN}

Gampong adalah sebuatan atas desa di Aceh. Merupakan suatu komunitas adat yang diakui negara berdasarkan asal usulnya. Oleh karenanya Gampong dipimpin oleh seorang Geuchik dan di dampingi Tuha Peuet sebagai lembaga musyawarah. Keberadaan Gampong pernah mengalami pasang surut, baik secara politik maupun kultural. Kondisi ini tercerminn dari eksistensinya dalam regulasi pada era sejak diberlakukannya Undang-Undang Nomor 5 Tahun 1979 tentang Pemerintahan Desa. Undang-Undang ini kemudian dicabut seiring dengan diberlakukannya Undang-Undang Nomor 22 Tahun 1999 tentang Pemerintahan Daerah.

Berkenaan dengan desa ini baru dibentuk perundang-undangan tersendiri sejak tahun 2014 senada dengan diundangkan Undang-Undang Nomor 6 Tahun 2014 tentang Desa. Keberadaan undang-undang ini merupakan era baru dalam penyelenggaraan pemerintahan pada tingkat desa sebagai kawasan otonomi terendah di Indonesia.

Keberadaan undang-undang itu di Aceh ditopang dengan landasan hukum berupa undangundang yang lain, yaitu Undang-undang Nomor 11 Tahun 2006 tentang Pemerintahan Aceh (UUPA). Dalam undang-undang ini Pemerintahan Gampong telah diakui sebagai wilayah yang otonom terendah di Aceh. Pasal 1 angka 20 undang-undang tersebut menyebutkan Gampong adalah kesatuan masyarakat hukum yang berada di bawah mukim dan dipimpin oleh Keuchik atau nama yang berhak menyelenggarakan urusan rumah tangga sendiri. Undang-undang ini memberikan kebebasan kepada setiap kabupaten/kota di Aceh untuk memakai nama lain terhadap Gampong ini, dapat Kampong atau desa, atau yang lainnya tergantung kabupaten/kota yang bersangkutan.

Dengan demikian, untuk mengembalikan Gampong atau nama lain yang dipakai disetiap kabupaten/kota sebagaimana hakikatnya sebuah wilayah yang otonom, tentunya diperlukan suatu penataan kembali. Penataan kembali tersebut tidak terlepas dari aspek regulasi, hal ini sebagaimana diamanatkan dalam Pasal 117 ayat (2) UUPA, bahwa mengenai kedudukan, fungsi, pembiayaan, organisasi dan perangkat pemerintahan Gampong atau nama lain diatur dengan qanun kabupaten/kota.

Kedua undang-undang tersebut telah memperkuat keberadaan Gampong di Aceh, baik dari ciri khasnya maupun dari segi sumber keuangan gampong. Hal ini terbukti, dimana Pemerintah Aceh untuk mengalokasi bantuan keuangan kepada gampong, yang disebut dengan Bantuan Keuangan Peumakmu Gampong (BKPG). Demikian pula oleh Pemerintah Pusat melakukan pemberian bantuan kepada Gampong yang disebut Alokasi Dana Desa (ADD).

Keberadaan keuangan gampong di satu sisi tentunya harus diacungkan jempol, karena adanya keuangan dimaksud adalah untuk mempercepat pembangunan di Gampong, yang selama ini pembangunannnya sangat tergantung pada Pemerintah Pusat, Pemerintah Provinsi dan Pemerintah Kabupaten/Kota. Keberadaan keuangan ini juga dapat mendorong partisipasi masyarakat untuk ikut merencanakan dari awal terhadap kebutuhan pembangunan di gampongnya. Pada sisi lain, keberadaan keuangan gampong yang melimpah dapat sumber masalah baru di gampong, apabila tidak dikelola dengan baik, bahkan dapat menyebabkan Geuchik dan perangkatnya berhadapan dengan masalah hukum, sebagaimana ditemukan dalam banyak kasus, bahkan berkurangnya semangat yang berasaskan kebersamaan.

Disinilah perlu adanya ketertiban dalam pengelolaan keuangan gampong. Ketertiban ini harus menjadi perhatian bagi semua pihak, baik Geuchik, Tuha Peuet, dan masyarakat serta pihak-pihak yang terkait dengannya. Tertib ini bukan hanya pada pencatatan, melainkan lebih luas, yaitu pada perencanaan, pengelolaan dan pertanggung jawabannya. Untuk itui, maka perlu dilakukan penelitian di Kabupaten Aceh Barat dalam upayan untuk mendorong pemerintahan gampong yang tertib di bidang pengelolaan keuangan. 


\section{METODE PENELITIAN}

Kajian ini menggunakan metode penelitian hukum normatif (legal research), yaitu. kajian yang mengacu kepada asas-asas, norma-norma yang terdapat dalam peraturan perundangundangan, mulai dari Undang-Undang, Peraturan Pemerintah, Peraturan Menteri, Qanun Kabupaten Aceh Barat, Peraturan Bupati Kabupaten Aceh Barat dan norma yang hidup dalam masyarakat. Oleh karena itu, kajian bersifat preskriptif, yaitu suatu proses mencari dan menemukan praktik di dalam masyarakat sebagai implementasi hukum berdasarkan kreativitas dan kearifan masyarakatan guna menjawab persoalan hukum dan adminstrasi pengelolaan keuangan Gampong yang baik.

Pendekatan yang digunakan dalam kajian ini, yakni pendekatan perundangan-undangan (state approach), dan pendekatan konsepsional (concept approach), dengan mengkaji bahan penelitian yang terdiri dari bahan hukum primer, sekunder dan tertier. Bahan penelitian dianalisis dengan pendekatan kualitatif, dengan tujuan untuk memahami makna dari bahan hukum yang telah dikumpulkan, yang kemudian ditafisrkan secara normatif, logis dan sistematis dengan menggunakan metode induktif.

\section{HASIL DAN PEMBAHASAN}

Gampong merupakan pemerintahan terendah dalam sistem pemerintahan di Indonesia. Sebagai negara hukum, maka maju dan mundurnya pemerintahan gampong sangat tergantung kepada aturan hukum yang ada. Oleh karena itu negara Indonesia sebagai negara hukum (Budiono Kusumohamidjojo, 1999: 147) harus memiliki arah kebijakan untuk mewujudkan harapan para warga masyarakat akan kehidupan yang tertib, adil dan sejahtera.

Hal ini dapat terlihat dimana cita-cita untuk membangun gampong yang pada beberapa dekade yang meletakkan kekuasan pembangunan gampong pada kabupaten/kota, bergeser pada pembangunan yang dilaksanakan oleh gampong secara mandiri. Pada beberapa dekade gampong hanya sebagai penerima pembangunan, dimana gampong tidak memiliki pengelolaan keuangan tersendiri yang bersumberkan dari anggaran dan pendapatan belanja negera.

Sumber dana pembangunan gampong yang masih dikelola oleh kabupaten/kota, telah melahirkan kreativitas dan kearifan lokal di tingkat gampong, yang berlandaskan pada semangat kegotong royongan. Hal ini ditandai dengan adanya swadaya masyarakat untuk membangun gampong, khususnya sarana mesjid. Masyarakat melakukan pengumpulan dana secara sukarela untuk membangun rumah ibadah dengan landasannya adalah untuk mendapatkan pahala dari Allah Swt.

Namun hal itu dipandang tidak cukup untuk mendorong agar gampong lebih maju dan mandiri, maka tidak heran didengungkan adanya harapan gampong perlu diberikan porsi sebagai wilayah otonomi pula dengan disertai pada pengganggaran, sesuai dengan prinsip "money follow fungtion". Hal itu mulai disahuti, seiring dengan adanya reformasi pemerintahan, dimana ditandai dengan adanya desentralisasi pemerintahan, maka kewenangan pemerintahan yang langsung ditangani oleh pemerintahan pusat dikurangi, sementara kewenangan pemerintahan daerah meningkat. Pada masa sistem pemerintahan yang terpusat, segala sesuatu sangat tergantung pada pemerintahan pusat dan hal ini menimbulkan kekecewaan luar biasa pada saerah (Bagir Manan, 2001:15).

Oleh karena itu timbullah keinginan untuk memberikan kesempatan dan keleluasaan kepada daerah dalam penyeenggaraan otonomi daerah. Oleh karena itu istilah desentralisasi dalam penyeenggaraan pemerintahan daerah di Indonesia sering diartikan sebagai peaksanaan otonomi daerah (Husni Jalil, 2010:208). Salah satu konsepsi dari otonomi adalah adanya desentralisasi. Desentralisasi didefinisikan adalah penyerahan wewenang pemerintahan oleh pemerintahan atasan kepada pemerintahan di bawahnya untuk mengatur dan mengurus urusan rumah tangganya. Mulai tahun 1999 dengan Undang-Undang Nomor 22 Tahun 1999 tentang 
Pemerintahan Daerah, otonomi daerah merupakan sebagai salah satu agenda yang perlu dilansir oleh pemerintah pasca orde baru digulirkan (H.A.W Wijaya, 2004: 74).

Setelah reformasi, maka pemerintahan memiliki dinamika baru, dimana daerah memiliki kewenangan untuk mengatur dan mengurus rumah tangganya sendiri, yang didalamnya terkandung 3 (tiga) hal utama, yaitu:

1. Pemberian tugas dan kewenangan untuk melaksanakan sesuatu yang sudah diserahkan kepada Pemerintah daerah;

2. Pemberian kepercayaan dan wewenang untuk memikirkan, mengambil indisiatif dan menetapkan seniri cara-cara pelaksanaan tugas tersebut;

3. Dalam upaya memikirkan, mengambil inisiatif dan mengambil keputusan tersebut, mengikutsertakan masyarakat baik secara langsung maupun melalui Dewan Perwakilan Rakyat Daerah (H.A.W Wijaya, 2004:2).

Pada masa ini, otonomi masih hanya berkutat pada pemerintahan daerah di tingkat provinsi dan kabupaten/kota sedangkan gampong belum menjadi tumpuan dalam memperkuat pemerintahan dan pembangunan di negeri ini. Hal ini dapat dilihat dari dibentuknya Peraturan Pemerintah Nomor 72 Tahun 2005 Tentang Desa. Peraturan pemerintah ini merupakan penjabaran dari ketentuan Pasal 216 ayat (1) Undang-Undang Nomor 32 Tahun 2004 Tentang Pemerintahan Daerah.

Meskipun Undang-Undang tersendiri belum terbentuk, namun upaya untuk menempatkan Gampong yang mandiri terus diupayakan, meskipun belum terealisasi pada Undang-Undang Nomor 32 Tahun 2004 tentang Pemerintahan Daerah, pada harapan itu telah ada pada pembentukan Undang-Undang Nomor 25 Tahun 2004 Tentang Sistem Perencanaan Pembangunan Nasional. Undang-undang ini dengan jelas menyebutkan bahwa pembangunan nasional di Indonesia merupakan upaya yang dilaksanakan oleh segenap komponen bangsa Indonesia dalam rangka mencapai tujuan bernegara.

Tahun 2014, merupakan sejarah baru dalam pembangunan Gampong, dimana dibentuknya Undang-Undang Nomor 6 Tahun 2014 tentang Desa. Menurut Undang-Undang ini, desa adalah kesatuan masyarakat hukum yang memiliki batas wilayah yang berwenang untuk mengatur dan mengurus urusan pemerintahan, kepentingan masyarakat setempat berdasarkan prakarsa masyarakat, hak asal usul, dan/atau hak tradisional yang diakui dan dihormati dalam sistem pemerintahan Negara Kesatuan Republik Indonesia.

Meskipun undang-undang ini membagi desa, menjadi dua, yaitu desa dan desa adat, namun gampong seharus dipertanyakan apakah termasuk desa atau desa adat. Namun demikian dari pengelolaan pemerintahan dan pembangunannya kedua jenis desa ini memiliki aturan yang sama dalam hal menyangkut ketertiban dalam pembangunan desa. Apabila termasuk dalam desa adat maka banyak sisi adat yang dapat diterapkan dalam pemerintahan dan pembangunan. Hal ini tidak berarti selama ini kearifan gampong tidak diakui dalam perundang-undangan.

Ketentuan Pasal 18 UU Desa menegaskan bahwa kewenangan Desa meliputi kewenangan di bidang penyelenggaraan Pemerintahan Desa, pelaksanaan Pembangunan Desa, pembinaan kemasyarakatan Desa, dan pemberdayaan masyarakat Desa berdasarkan prakarsa masyarakat, hak asal usul, dan adat istiadat Desa. Dengan demikian, maka gampong sudah mulai mengelola keuangan sendiri terhadap pembangunan pada skala gampong, yang dapat mempercepat gampong lebih maju. Hal ini karena keadaan keuangan sangat menentukan bentuk, cara serta kemungkinan-kemungkinan kegiatan yang akan dilaksanakan oleh suatu pemerintahan (Faisal A. Rani, 2010: 242).

Disisi lain, penggunan keuangan gampong memiliki ketertiban, dalam arti punya tata tertib yang harus diikuti. Ketertiban dalam pembangunan gampong harus mencakup pada keseluruhan tahapan proses pembangunan gampong, yang dimulai pada perencanaan, pelaksanaan pembangunan dan pelaporan atas penggunaan keuangan gampong. Untuk tertib pembangunan 
di gampong, maka ketentuan Pasal 24 UU Desa, mengharuskan penyelenggaraan Pemerintahan Gampong berdasarkan asas:
a. kepastian hukum;
b. tertib penyelenggaraan pemerintahan;
c. tertib kepentingan umum;
d. keterbukaan;
e. proporsionalitas;
f. profesionalitas;
g. akuntabilitas;
h. efektivitas dan efisiensi;
i. kearifan lokal;
j. keberagaman; dan
k. partisipatif.

Untuk implementasi asas-asas itu Kementrian Dalam Negeri melalui Peraturan Menteri Dalam Negeri Nomor 114 Tahun 2014 Tentang Pedoman Pembangunan Desa menegaskan perlu bagi setiap gampong untuk mengikuti kaedah-kaedah dalam pembangunan gampong itu.

\section{Perencanaan Gampong}

Menurut ketentuan Pasal 4 Peraturan Menteri Dalam Negeri Nomor 114 Tahun 2014 Tentang Pedoman Pembangunan Desa, pada tingkat gampong diwajibkan membuat perencanaan pembangunan, dimana perencanaan itu disusun secara berjangka, sehingga pada setiap gampong dikenal dua jenis perencanaan, yaitu:

a. Rencana Pembangunan Jangka Menengah Desa untuk jangka waktu 6(enam) tahun; dan

b. Rencana Pembangunan Tahunan Desa atau yang disebut Rencana Kerja Pemerintah Desa, merupakan penjabaran dari RPJM Desa untuk jangkawaktu 1 (satu) tahun.

Adanya kedua jenis perencanaan adalah untuk menjaga kesinambungan antara pembangunan setiap tahunnya, meskipun Keuchik dan Tuha Peuet dilakukan pergantian. Untuk tertibnya perencanaan itu, dalam arti semua merasa memiliki dan tidak ada yang merasa tidak dilibatkan, maka perencanaan itu harus dibuat dalam suatu musyawarah gampong. Musyawarah meruapakan suatu kewajiban oleh Keuchik selaku kepela pemerintah di Gampong.

Adanya forum musyawarah ini bagi masyarakat di gampong bukan suatu hal baru, karena sejak dahulu di Aceh sudah membudaya dengan musyawarah itu. Setiap kegiatan di gampong dimulai dengan musyawarah. Oleh karena itu disetiap gampong di Aceh terdapat "Meunasah", dimana meunasah ini merupakan tempat bagi warga masyarakat di Gampong untuk melakukan musyawarah, selain sebagai tempat pendidikan Al-Quran bagi anak-anak. Oleh karena itu tidak heran menunjukkan adanya bukti bahwa meunasah sudah ada sejak terbentuknya masyarakat Islam di Aceh (http://www.atjehcyber.net/2011/06/meunasah-pusat-peradaban-asyarakat. html?m=1).

Forum musyawarah ini oleh Keuchik selain melibatkan Tuha Peuet, juga melibatkan warga masyarakat, hanya saja tingkat partisipasi dari beberapa unsur yang kurang mendapatkan keterwakilan, misalnya kaum perempuan, anak-anak dan kaum disabilitas, yang akhir-akhir ini disuarakan untuk diikutsertakan dalam setiap proses musyawarah gampong.

Persoalan pengelolaan dana gampong dengan berbagai aturan yang berasal dari sistem keuangan negara merupakan hal baru bagi masyarakat, sehingga terdapat beberapa ketentuan yang harus diikuti. Hal ini sebagai konsekwensi dari adanya pendapatan gampong dari berbagai sumber, yaitu:

a. pendapatan asli Desa terdiri atas hasil usaha, hasil aset, swadaya dan partisipasi, gotong royong, dan lain-lain pendapatan asli Desa; 
b. alokasi Anggaran Pendapatan dan Belanja Negara;

c. bagian dari hasil pajak daerah dan retribusi daerah Kabupaten/Kota;

d. alokasi dana Desa yang merupakan bagian dari dana perimbangan yang diterima Kabupaten/Kota;

e. bantuan keuangan dari Anggaran Pendapatan dan Belanja Daerah Provinsi dan Anggaran Pendapatan dan Belanja Daerah Kabupaten/Kota;

f. hibah dan sumbangan yang tidak mengikat dari pihak ketiga; dan

g. lain-lain pendapatan Desa yang sah.

Dengan banyaknya sumber pendapatan, maka dapat dipastikan anggaran pembangunan gampong jadi semakin besar pula dan setiap tahunnya terus bertambah, dengan demikian diharapkan otonomi pada tingkat gampong akan semakin berhasil pula (bandingkan dengan Josef Riwu Kaho, 2007: 138). Oleh karena itu aspek perencanaan menjadi sangat penting agar sumber daya yang ada dapat bermanfaat bagi seluruh masyarakat. Ketentuan Pasal 2 Peraturan Menteri Dalam Negeri Nomor 114 Tahun 2014 Tentang Pedoman Pembangunan Desa menegaskan bahwa:

(1) Pemerintah Desa menyusun perencanaan Pembangunan Desa sesuai dengan kewenangannya dengan mengacu pada perencanaan pembangunan Kabupaten/Kota.

(2) Pembangunan Desa sebagaimana dimaksud pada ayat (1) dilaksanakan oleh Pemerintah Desa dengan melibatkan seluruh masyarakat Desa dengan semangat gotong royong.

(3) Masyarakat Desa berhak melakukan pemantauan terhadap pelaksanaan Pembangunan Desa.

Oleh karena itu terdapat peran pemerintah kabupaten dan kecamatanan untuk mendampingi terhadap kegiatan musyawarah gampong, dengan tidak melakukan intervensi terhadap kewenangan yang dimiliki oleh masyaarakat dari gampong yang bersangkutan. Ketentuan Pasal 2 menegaskan bahwa dalam rangka perencanaan dan pelaksanaan pembangunan Desa, pemerintah Desa didampingi oleh pemerintah daerah kabupaten/kota yang secara teknis dilaksanakan oleh satuan kerja perangkat daerah kabupaten/kota. Demikian pula oleh tenaga pendamping profesional, kader pemberdayaan masyarakat Desa, dan/atau pihak ketiga, dimana Camat bertindak selaku koordinator dalam pendampingandi wilayahnya masing-masing.

Pendampingan ini penting, karena setiap tahun pemerintah pusat menetapkan alokasi anggaran yang terus meningkat untuk gampong, dan setiap tahun pula ditetapkan prioritas penggunaan anggaran itu. Demikian pula, dalam penentuan skala prioritas yang bagi masyarakat belum terbiasa untuk itu.

Menindak lanjuti hal tersebut, maka sejak bergulirnya kewajiban menyusun perencanaan di gampong untuk pengelolan dana di gampong, oleh Pemerintah Kabupaten Aceh sejak tahun 2016 telah melakukan perlombaan perencanaan gampong, dan untuk tahun 2017 sudah dilaksanakan untuk kedua kalinya. Adapun perlombaan ini dilakukan untuk mendorong bagi masyarakat gampong untuk menyusun perencanaan bardasarkan partisipasi masyarakat berdasarkan kebutuhan yang nyata di Gampong. Selain itu, perlombaan ini dimaksudkan untuk melakukan evaluasi terhadap proses dan hasil perencanaan di Gampong.

\section{Pelaksanaan Pembangunan}

Pelaksana pembangunan pada tingkat gampong yang bersumberkan anggaran pendapatan dan belanja gampong ikordinasikan oleh keuchik yang dilaksanakan oleh perangkat Desa dan/atau unsur masyarakat Desa. Pembangunan ini dapat dikelola melalui swakelola gampong, kerjasama antar gampong dan/atau kerjasama gampong dengan pihak ketiga. Lebih jauh lagi, ketentuan Pasal 63 Peraturan Menteri Dalam Negeri Nomor 114 Tahun 2014 Tentang Pedoman Pembangunan Desa menegaskan, bahwa "Pelaksanaan kegiatan pembangunan Desa 
mengutamakan pemanfaatansumberdaya manusia dan sumberdaya alam yang ada di Desa sertamendayagunakan swadaya dan gotong royong masyarakat".

Hal ini menunjukkan bahwa pelaksana pembangunan di gampong dilaksanakan oleh masyarakat melalui sistem swakelola, hal ini dapat pula menampung lapangan kerja bagi masyarakat setempat. Aturan menghendaki semangat gotong royong tidak hilang dengan adanya sumber pendapatan dari negara dalam membangun, yang seharusnya menjadi modal sebagai capital ditambah dengan modal pembangunan lainnya yang berasal dari masyarakat, yaitu gotomg royong.

Masyarakat harus menyadari bahwa pemerintah mempunyai keterbatasan dana dan daya untuk melaksanakan pembangunan karena pembangunan itu sendiri sangat kompleks, sehingga diharapkan dapat tercipta saling isi mengisi antara pemerintah dan masyarakat. Prinsp kebersamaan ini pada dasarnya meletakkan tanggung jawab pembangunan gampong bukan hanya dipundak Pemerintah Gampong, tetapi bersama masyarakat juga (Sondang Siagian, 2005: 4).

Gotong royong ini dapat pula dilakukan untuk kegiatan pembanguan yang merupakan lintas gampong, melalui pola kerjasama dengan gampong yang lain. Meskipun demikian pula hal ini tidak ditutup adanya peluang bagi pihak ketiga untuk menjadi pelaksana kegiatan, apalagi masyarakat setempat tidak mampu melaksanakannya. Pelibatan pihak ketiga ini dilakukan melalui pengadaan barang dan/atau jasa dengan berpedoman pada peraturan bupati/walikota yang berpedomanpada ketentuan peraturan perundang-undangan tentang pengadaan barang dan jasa.

Undang-undang juga mewajibkan dalam pelaksana pembangunan di gampong untuk menganut asas transparasi, dalam arti masyarakat berhak atas informasi atas pelaksana pembangunan di gampong. Adanya transparansi ini merupakan kegiatan administrasi, karena administrasi diartikan sebagai: (1) usaha dan kegiatan yang meliputi penetapan tujuan serta penetapan cara-cara penyelenggaraan pembinaan organisasi; (2) usaha dan kegiatan yang berkaitan dengan penyelenggaraan kebijaksanaan serta mencapai tujuan; (3) kegiatan yang berkaitan dengan penyelenggaraan pemerintahan; (4) kegiatan kantor dan tata usaha (Kamus Besar Bahasa Indonesia, Balai Pustaka, Jakarta, 1994: 8).

Asas transparansi ini merupakan asas-asas umum pemerintahan yang baik, bukan hanya dituntut bagi pelaksanaan pembangunan di gampong saja, melainkan pada semua tingkat pemerintahan, demikian pula bagi setiap organisasi, baik organisasi pemerintah maupun organisasi swasta. Pasal 1 angka 17 Undang-Undang Nomor 30 Tahun 2014 Tentang Administrasi Pemerintahan menjelaskan bahwa Asas-asas Umum Pemerintahan yang Baik yang selanjutnya disingkat AUPB adalah prinsip yang digunakan sebagai acuan penggunaan Wewenang bagi Pejabat Pemerintahan dalam mengeluarkan Keputusan dan/atau Tindakan dalam penyelenggaraan pemerintahan.

Undang-undang ini menegaskan bahwa tujuan Undang-Undang tentang Administrasi Pemerintahan adalah:

a. menciptakan tertib penyelenggaraan Administrasi Pemerintahan;

b. menciptakan kepastian hukum;

c. mencegah terjadinya penyalahgunaan Wewenang;

d. menjamin akuntabilitas Badan dan/atau Pejabat Pemerintahan;

e. memberikan pelindungan hukum kepada Warga Masyarakat dan aparatur pemerintahan;

f. melaksanakan ketentuan peraturan perundang-undangan dan menerapkan AUPB; dan

g. memberikan pelayanan yang sebaik-baiknya kepada Warga Masyarakat.

Adanya administrasi gampong dalam pelaksanaan pembangunan di gampong juga selaras dengan adanya hak masyarakat untuk mendapatkan informasi atas pelaksanaan pembangunan di gampong sebagaimana diakui dalam Undang-Undang Desa, yang termaktub dalam Pasal 68, bahwa masyarakat berhak meminta dan mendapatkan informasi dari Pemerintah Desa serta 
mengawasi kegiatan penyelenggaraan Pemerintahan Desa, pelaksanaan Pembangunan Desa, pembinaan kemasyarakatan Desa, dan pemberdayaan masyarakat Desa.

Oleh karena itu pelaksanaan pembangunan di gampong harus dilakukan secara tertib adminsitrasi, baik bentuknya maupun isinya. Dalam arti pelaksanaan pembangunan di gampong harus dilaksanakan sesuai ketentuan yang ada, dan menghindari yang namanya mark up harganya, apalagi perbuatan-perbuatan yang menjurus pada adanya korupsi.

Dengan mengacu pada Undang-Undang Nomor 14 Tahun 2008 Tentang Keterbukaan Informasi Publik, pada kegiatan pembangunan gampong terdapat informasi yang perlu diketahui oleh masyarakat gampong. Undang-undang ini menyebutkan informasi Publik adalah informasi yang dihasilkan, disimpan, dikelola, dikirim, dan/atau diterima oleh suatu badan publik yang berkaitan dengan penyelenggara dan penyelenggaraan negara dan/atau penyelenggara dan penyelenggaraan badan publik lainnya yang sesuai dengan Undang-Undang ini serta informasi lain yang berkaitan dengan kepentingan publik.

Keterbukaan informasi di gampong adalah sesuatu yang tidak dilepaskan dengan adanya kewajiban dari tertib administrasi gampong sebagai mana dikehendaki oleh Undang-Undang Administrasi Pemerintahan. Artinya tujuan dari Undang-Undang Admistrasi Pemerintahan di atas selaras dengan tujuan dari Undang-Undang Keterbukaan Informasi Publik, yang menyebutkan bertujuan untuk:

a. menjamin hak warga negara untuk mengetahui rencana pembuatan kebijakan publik, program kebijakan publik, dan proses pengambilan keputusan publik, serta alasan pengambilan suatu keputusan publik;

b. mendorong partisipasi masyarakat dalam proses pengambilan kebijakan publik;

c. meningkatkan peran aktif masyarakat dalam pengambilan kebijakan publik dan pengelolaan Badan Publik yang baik;

d. mewujudkan penyelenggaraan negara yang baik, yaitu yang transparan, efektif dan efisien, akuntabel serta dapat dipertanggungjawabkan;

e. mengetahui alasan kebijakan publik yang mempengaruhi hajat hidup orang banyak;

f. mengembangkan ilmu pengetahuan dan mencerdaskan kehidupan bangsa; dan/atau

g. meningkatkan pengelolaan dan pelayanan informasi di lingkungan Badan Publik untuk menghasilkan layanan informasi yang berkualitas.

Selaras dengan hak masyarakat untuk mendapatkan informasi, maka ketentuan Pasal 7 undang-undang ini menegaskan tentang adanya kewajiban bagi Badan Publik wajib menyediakan, memberikan dan/atau menerbitkan Informasi Publik yang berada di bawah kewenangannya kepada Pemohon Informasi Publik, selain informasi yang dikecualikan sesuai dengan ketentuan. Kewajiban ini dilaksanakan dengan membangun dan mengembangkan sistem informasi dan dokumentasi untuk mengelola Informasi Publik secara baik dan efisien sehingga dapat diakses dengan mudah. Senada dengan itu, hasil pengamatan menujukkan bahwa gampong telah mulai mempublikasi anggaran gampong beserta rencana peruntukkannya. Lebih dari itu, dalam setiap pelaksanaan kegiatan, oleh pelaksana kegiatan telah menempatkan papan informasi kegiatan, baik nama kegiatan maupun jumlah anggaran yang diperuntukkan untuk kegiatan itu.

Sebagai pertanggung jawaban atas penggunaan uang negara, maka untuk memastikan kegiatan yang dilaksanakan sesuai rencana, maka perlu dilakukan pemeriksaan. Dalam hal ini Keuchik bertanggung jawab untuk mengoordinasikan pemeriksaan tahap perkembangan dantahap akhir kegiatan infrastruktur gampong. Pemeriksaan ini dapat dibantu olehtenaga ahli di bidang pembangunan infrastruktur sesuai dengan dokumen Rencana Kerja Pembangunan Gampong. Penyediaan tenaga ahli harus mengutamakan pemanfaatan tenaga ahli yang berasal dari masyarakat gampong, dengan tetap memungkinkan meminta bantuan kepada Bupati melalui camat perihal kebutuhan tenaga ahli di bidang pembangunan infrastruktur yang dapat 
berasal satuan kerja perangkat daerah kabupaten yangmembidangi pekerjaan umum dan/atau tenaga pendamping profesional.

Pengamatan dilapangan menunjukkan bahwa dalam pelaksanaan pembangunan di gampong, masih banyak ditemukan adanya permasalahan. Permasalahan ini tentunya sangat dipahami karena merupakan hal baru di tengah-tengah masyaratkat. Namun permasalahan itu tidak boleh dibiarkan, melainkan harus diselesaikan secara arif dan bijaksana sesuai dengan kaedah hukum. Oleh karena itulah, maka penyelesaian masalah harus dilakukan secara mandiri oleh gampong berdasarkan kearifan lokal dan pengarus utamaan perdamaian melalui musyawarah gampong. Dalam hal musyawarah Gampong menyepakati masalah dinyatakan selesai, hasil kesepakatan dituangkan dalam berita acara musyawarah gampong.

Namun sebagai catatan bahwa tidak semua masalah dapat diselasaikan secara musyawarah, dalam hal terjadinya tindak pidana korupsi dalam pelaksana kegiatan di Gampong, meskipun demikian maka sudah selayaknya kepada pihak yang menangani perkara pidana ini untuk secara bijak pula melihat titik masalah, karena Keuchik masih sangat minim pengetahuan tentang tertib administrasi pengelolaan keuangan gampong.

\section{Pelaporan Pelaksanaan Kegiatan}

Kegiatan yang dilaksanakan dengan mengunakan anggaran gampong wajib dilaporkan kepada Keuchik. Penyampaian laporan ini wajib disesuaikandengan jenis kegiatan dan tahapan penyaluran dana kegiatan. Laporan kegiatan disusun berdasarkan pertanggungjawaban terhadap penggunaan dana yangditerima dan tahapan perkembangan pelaksanaan kegiatan.

Laporan dituangkan dalam format laporan hasil pelaksanaan kegiatan pembangunan gampong. Format laporan dilampiri dengan dokumentasi hasil pelaksanaan kegiatan pembangunan gampong yangsekurang-kurangnya meliputi:

a. realisasi biaya beserta lampiran bukti-bukti pembayaran;

b. foto kegiatan infrastruktur Desa kondisi $0 \%, 40 \%, 80 \%$ dan $100 \%$ yang diambil dari sudut pengambilan yang sama;

c. foto yang memperlihatkan orang sedang bekerja dan/atau melakukan kegiatan secara beramai-ramai;

d. foto yang memperlihatkan peran serta masyarakat dalam kegiatan pembangunan Desa;

e. foto yang memperlihatkan pembayaran upah secara langsung kepada tenaga kerja kegiatan pembangunan Desa; dan

f. gambar purna laksana untuk pembangunan infrastruktur Desa.

Berdasarkan laporan pelaksanaan pembangunan kegiatan dari para pelaksana, maka Keuchik menyusun laporan penyelenggaraan pemerintahan Gampong yang disampaikan kepada Tuha Peuet Gampong untuk dilakukan musayawarah gampong, karena pada prinsipnya Tuha Peuet, memiliki kewenangan untuk menyelesaikan masalah di tingkat Gampong, pihak lain harus memberikan kesempatan kepada aparat gampong dan Mukim sesuai area kegiatan dan tingkatan pemerintahan (Taqwaddin, 2010.:14).

Oleh karena itu semua pihak, baik masyarakat gampong maupun pihak lain harus menghormati kearifan pada tingkat gampong. Pengakuan dan penghormatan ini akan melahirkan kepastian hukum dan tertib hukum di tengah-tengah masyarakat, sesuai tujuan pokok dari hukum adalah ketertiban (Cut Asmaul Husna, 2012:61), dan produk hukum harus dibentuk untuk mendorong terbentuknya masyarakat yang sehat dan dinamis (Diana Ediana Rae, 2008:1)

Dari segi adat, di gampong dikenal Majelis Peradilan Gampong, dimana Keuchik dan Tuha Peut dapat menyelesaikan sengketa di gampong. Untuk memperkuat putusan Tuha Peut, maka ketentuan Pasal 82 Peraturan Menteri Dalam Negeri Nomor 114 Tahun 2014 Tentang Pedoman Pembangunan Desa menegaskan bahwa masyarakat berpartisipasi menanggapi laporan pelaksanaan pembangunan gampong, adalah suatu hal untuk saling melengkapi dan mengisi 
dalam mengambil keputusan.Tanggapan masyarakat tersebut disampaikan dengan memberikan masukan kepada Keuchik.Selanjutnya Tuha Peuet, Keuchik, pelaksana kegiatan danmasyarakat Desa membahas dan menyepakati tanggapan dan masukanmasyarakat untuk dicarikan kesepakatan. Hasil kesepakatan dituangkan dalam berita acara.

Adanya partisipasi masyarakat untuk menyelesaikan secara musyawarah ini berkaitan dari adanya kewajiban masyarakat gampong menurut Pasal 68 ayat (2) UU Desa untuk membangun diri dan memelihara lingkungan Desa, mendorong terciptanya situasi yang aman, nyaman, dan tenteram di Desa, memelihara dan mengembangkan nilai permusyawaratan, permufakatan, kekeluargaan, dan kegotongroyongan di Desa; dan berpartisipasi dalam berbagai kegiatan di gampong.

\section{SIMPULAN}

Pembangunan milik semua warga masyarakat, baik merencanakan, melaksanakan maupun menikmatinya. Oleh karena itu prinsip kebersamaan dalam pembangunan menjadi catatan penting bagi setiap warga negara Indonesia. Sejak bergulirnya Gampong yang memiliki otonomi sebagaimana dimaksudkan daam Undang-Undang Desa sumber daya pembangunan tidak hanya didasarkan pada penggunaan sumber daya gampong saja, melainkan sudah termasuk dalam anggaran pembangunan nasional yang tercantum dalam APBN. Gotong-gotong sebagai kearifan lokal tetap harus dipertahankan, meskipun budaya gotong royong menjadi berkurang. Hal ini karenakehadiran uang negara dalam membanguan Gampong bukan dianggap sebagai energi tambahan melainkan sebagai sumber utama. Dari sisi perencanaan dan pelaksana pembangunan gampong masih menunjukkan adanya kendala, namun keberadaan musyawarah gampong telah banyak masalah dapat diselesaikan, karena musyawarah musyawarah tetap menjadi solusi terdepan di gampong dalam menyelesaikan masalah. Musyawarah ini dapat berlangsung dengan baik karena adanya keterbukaan dari berbagai elemen dalam melihat masalah.

\section{REFERENSI}

A.W Wijaya, 2004. Otonomi Daerah dan Daerah Otonom. Jakarta: PT Rajagrafindo Persada.

Bagir Manan, 2001. Menyongsong Fajar Otonomi Daerah. Yogyakarta: Pusat Studi Hukum Fakultas Hukum Universitas Islam Indonesia.

Budiono Kusumohamidjojo, 1999. Ketertiban Yang Adil, Problematika Filsafat Hukum. Jakarta: Grasindo.

Cut Asmaul Husna, 2012. "Penemuan dan Pembentukan Hukum" Jurnal Hukum PPs MHUNPAB MIZAN Vol. 2 No. 3.

Diana Ediana Rae, Mencari Bentuk Regulasi Ekonomi Yang Efisien dan Kompetitif, Legalitas. Org, 21 Januari 2008.

Faisal A. Rani, 2010. "Kontribusi Pendapatan Asli Daerah dalam APBD sebagai Indikator Keberhasilan" Jurnal Ilmu Hukum KANUN Nomor 51 Tahun XII.

Husni Jalil, 2010. "Implementasi Otonomi Khusus di Provinsi Aceh Berdasarkan UndangUndang No. 11 Tahun 2006" Jurnal Ilmu Hukum KANUN Nomor 51 Tahun XII.

Josef Riwu Kaho, 2007. Prospek Otonomi Daerah di Negara Republik Indonesia, Identifikasi Faktor-faktor Yang Mempengaruhi Penyelenggaraan Otonomi Daerah. Jakarta: Raja Grafindo Persada.

Kamus Besar Bahasa Indonesia, Balai Pustaka, Jakarta, 1994

Sondang Siagian, 2005. Administrasi Pembangunan, Konsep, Diensi, dan Strateginya. Jakarta: Bumi Aksara.

Taqwaddin, 2010. “Aspek Legal Penguasaan Hutan oleh Mukim” Jurnal Ilmu Hukum KANUN Nomor 51 Tahun XII. 